\title{
Correlation between brain tissue oxygen tension and regional cerebral oximetry in uninjured human brain under conditions of changing ventilation strategy
}

\author{
Paul Picton ${ }^{1}$. Phillip E. Vlisides ${ }^{1} \cdot$ Magnus K. Teig $^{1} \cdot$ Jason A. Heth ${ }^{1} \cdot$ Daniel Orringer ${ }^{1} \cdot$ Joseph Brooks $^{1}$. \\ Amy McKinney ${ }^{1} \cdot$ Graciela Mentz $^{1}$. George A. Mashour ${ }^{1}$
}

Received: 16 November 2021 / Accepted: 25 January 2022 / Published online: 3 February 2022

(c) The Author(s), under exclusive licence to Springer Nature B.V. 2022

\begin{abstract}
Controversy surrounds regional cerebral oximetry $\left(\mathrm{rSO}_{2}\right)$ because extracranial contamination and unmeasured changes in cerebral arterial:venous ratio confound readings. Correlation of $\mathrm{rSO}_{2}$ with brain tissue oxygen $\left(\mathrm{PbrO}_{2}\right)$, a "gold standard" for cerebral oxygenation, could help resolve this controversy but $\mathrm{PbrO}_{2}$ measurement is highly invasive. This was a prospective cohort study. The primary aim was to evaluate correlation between $\mathrm{PbrO}_{2}$ and $\mathrm{rSO}_{2}$ and the secondary aim was to investigate the relationship between changing ventilation regimens and measurement of $\mathrm{PbrO}_{2}$ and $\mathrm{rSO}_{2}$. Patients scheduled for elective removal of cerebral metastases were anesthetized with propofol and remifentanil, targeted to a BIS range 40-60. $\mathrm{rSO}_{2}$ was measured using the INVOS 5100B monitor and $\mathrm{PbrO}_{2}$ using the Licox brain monitoring system. The Licox probe was placed into an area of normal brain within the tumor excision corridor. $\mathrm{FiO}_{2}$ and minute ventilation were sequentially adjusted to achieve two set points: (1) $\mathrm{FiO}_{2} 0.3$ and $\mathrm{paCO}_{2} 30 \mathrm{mmHg}$, (2) $\mathrm{FiO}_{2} 1.0$ and $\mathrm{paCO}_{2} 40 \mathrm{mmHg}$. $\mathrm{PbrO}_{2}$ and $\mathrm{rSO}_{2}$ were recorded at each. Nine participants were included in the final analysis, which showed a positive Spearman's correlation $(\mathrm{r}=0.50, p=0.036)$ between $\mathrm{PbrO}_{2}$ and $\mathrm{rSO}_{2}$. From set point 1 to set point 2, $\mathrm{PbrO}_{2}$ increased from median 6.0, IQR 4.0-11.3 to median 22.5, IQR 9.8-43.6, $p=0.015 ; \mathrm{rSO}_{2}$ increased from median 68.0, IQR 62.5-80.5 to median 83.0, IQR 74.0-90.0, $p=$ 0.047. Correlation between $\mathrm{PbrO}_{2}$ and $\mathrm{rSO}_{2}$ is evident. Increasing $\mathrm{FiO}_{2}$ and $\mathrm{PaCO}_{2}$ results in significant increases in cerebral oxygenation measured by both monitors.
\end{abstract}

Keywords Brain tissue oxygen tension · End tidal carbon dioxide $\cdot$ Inspired oxygen fraction $\cdot$ Regional cerebral oximetry · Ventilation strategy

\section{Introduction}

Controversy surrounds the use of cerebral near infrared spectroscopy (NIRS) as a measure of true cerebral oxygenation because extracranial contamination has been demonstrated for cerebral oximeters from several manufacturers; saturation signals obtained from the scalp interfere with those obtained more exclusively from the brain [1]. Furthermore, cerebral arterial:venous ratio is assumed fixed within device software algorithms [2], thereby acting as an unmeasured confounder. Despite these concerns, cerebral oximetry is

Paul Picton

ppicton@med.umich.edu

1 Department of Anesthesiology, University of Michigan Medical School, Ann Arbor, MI, USA still used in multiple clinical settings [3]; decreases below an absolute measure of $50 \%$ or relative decreases of $20 \%$ appear to associate with cerebral ischemia [2] and low baseline values are associated with poor perioperative outcome [4].

The measurement of brain tissue oxygen $\left(\mathrm{PbrO}_{2}\right)$ is used in routine neurosurgery [5] and has been shown to reliably demonstrate cerebral hypoxia following traumatic brain injury [6]. It is the most direct measure of cerebral oxygenation, but probe insertion is highly invasive and hence precludes use outside of the neurosurgical or neurocritical care setting. Correlation between $\mathrm{rSO}_{2}$ and jugular bulb monitoring has been demonstrated under conditions of varying inspired oxygen fraction $\left(\mathrm{FiO}_{2}\right)$ in both uninjured [7] and injured human brain [8], but no study has been specifically designed to correlate $\mathrm{PbrO}_{2}$ (the most reliable) and $\mathrm{rSO}_{2}$ (the least invasive) as measures of cerebral oxygenation. Here, we test the hypothesis that $\mathrm{PbrO}_{2}$ and $\mathrm{rSO}_{2}$ correlate under 
conditions of varying $\mathrm{FiO}_{2}$ and partial pressure of carbon dioxide in arterial blood $(\mathrm{PaCO} 2)$ in uninjured, human brain .

\section{Methods}

The primary aim of this prospective single center cohort study was to evaluate for correlation between $\mathrm{PbrO}_{2}$ and $\mathrm{rSO}_{2}$ under the conditions of varying $\mathrm{FiO}_{2}$ and $\mathrm{PaCO}_{2}$ in uninjured human brain. The secondary aim was to investigate the relationship between changing ventilation strategy with both $\mathrm{PbrO}_{2}$ and $\mathrm{rSO}_{2}$. The study was approved by the Institutional Review Board of the University of Michigan, Ann Arbor, prior to study initiation (HUM00105648, 1/14/2016) and registered with an appropriate clinical trials registry (ClinicalTrials.gov: NCT03128957, 25/4/2017). Following written informed consent, we recruited adult patients at Michigan Medicine who were scheduled for elective excision of secondary cerebral metastases under general anesthesia. Consent was obtained by a study team member during the surgical preoperative evaluation. Patients were excluded if they refused to give consent, required prone positioning, had clinical or radiological evidence of elevated intracranial pressure, coagulopathy, were taking therapeutic agents known to increase bleeding risk, a history of cardiovascular disease, cerebrovascular disease, suffered from respiratory failure, or were not fluent English speakers. Since skin pigmentation may impact $\mathrm{rSO}_{2}$ values [9] and the study was small, recruitment was limited to Caucasian patients. All patients were subject to the same two-step variation in ventilation strategy.

Following pre-oxygenation, anesthesia was induced using fentanyl $(1-2 \mathrm{mcg} / \mathrm{kg})$ and propofol $(0.5-2 \mathrm{mg} / \mathrm{kg})$. Muscle relaxation was initiated and maintained as clinically indicated. The patient's trachea was intubated, and their lungs ventilated to achieve an $\mathrm{FiO}_{2}$ and $\mathrm{PaCO}_{2}$ determined by the study protocol. General anesthesia was maintained by total intravenous anesthesia (TIVA) with a combination of propofol $(80-150 \mathrm{mcg} / \mathrm{kg} / \mathrm{min})$ and remifentanil $(0.05-0.1 \mathrm{mcg} /$ $\mathrm{kg} / \mathrm{min}$ ) targeted to a Bispectral Index range 40-60 (BIS; Covidien, Boulder, CO).

Routine perioperative monitoring and invasive blood pressure monitoring was used for all patients. $\mathrm{rSO}_{2}$ was measured using the INVOS 5100B monitor (Somanetics Corporation, Troy, MI) and $\mathrm{PbrO}_{2}$ using the Licox brain tissue oxygen monitoring system (Integra LifeSciences Corporation, Plainsboro, $\mathrm{NJ}$ ). BIS and $\mathrm{rSO}_{2}$ optodes were applied, before induction of anesthesia, by a single researcher on the patient's forehead, as recommended by the manufacturer. Baseline $\mathrm{rSO}_{2}$ readings were recorded in the preoperative holding room with the patient sitting and breathing room air.

Licox probes are most typically placed and secured via a bolt inserted into the skull. Even with this highly invasive approach, the technique is reported to be safe [10], with hematoma as the main complication occurring in $<2 \%$ patients [11]. Here, a bolt was not used. The Licox probe was instead placed under direct vision into an area of normal brain within the future tumor excision corridor by the attending neurosurgeon, hence minimizing risk $[5,12,13]$. The probe was secured in place and allowed to equilibrate while maintaining close supervision of the surgical field to ensure that there was no undue edema or bleeding.

The starting tidal volume was set at $6-8 \mathrm{ml} / \mathrm{kg}$ and adjustments made by changing respiratory rate rather than tidal volume. During a pause in surgery, $\mathrm{FiO}_{2}$ and minute ventilation were sequentially adjusted to achieve the following pairs of ventilation set points:

(1) $\mathrm{FiO}_{2} 0.3$ and $\mathrm{PaCO}_{2} 30 \mathrm{mmHg}$

(2) $\mathrm{FiO}_{2} 1.0$ and $\mathrm{PaCO}_{2} 40 \mathrm{mmHg}$

Following a change in inspired gas composition, $\mathrm{PaO}_{2}$, $\mathrm{PaCO}_{2}, \mathrm{PbrO}_{2}$ and $\mathrm{rSO}_{2}$ were recorded at each set point, once both device readings had stabilized. Blood pressure, heart rate, hematocrit, BIS value, and propofol and remifentanil infusion rates were also recorded at each set point. The anesthesiologist and surgeon caring for the patient were blinded to the measures of cerebral oxygenation. $\mathrm{N}_{2} \mathrm{O}$, a possible confounding factor, was not used. If bolus doses of phenylephrine were required, recording was delayed because this pressor is associated with a reduction in $\mathrm{rSO}_{2}$ of approximately $3 \%$ which is sustained for several minutes [14]. Demographic and intraoperative data were retrieved from the patient's electronic medical records.

\subsection{Statistical analysis}

Exploratory data analysis was used to describe measures. Extreme values were identified using the Tukey Fences approach. Spearman's correlation was used to test for correlation between $\mathrm{PbrO} 2$ and $\mathrm{rSO} 2$ under conditions of varying ventilation strategy. Given the small sample size, and to be conservative in our approach, the analysis was not adjusted for repeated measures. When comparing $\mathrm{PbrO}_{2}$ and $\mathrm{rSO}_{2}$, we also standardized both measures to a z-score. This transformation facilitates comparison across quantities with different measurement units. A pre-study power analysis and sample size determination indicated that a sample size of 15 would achieve an $80 \%$ power with a one-sided type I error of 5\% to detect a positive correlation of 0.6 (from the null hypothesis of no correlation) between $\mathrm{PbrO}_{2}$ and $\mathrm{rSO}_{2}$ subsequent on alterations made in ventilation strategy. $P$ values $<0.05$ were considered statistically significant. 


\section{Results}

COVID-19 disrupted neurosurgical case volume and, consequently, recruitment for this study. Nineteen patients were screened for eligibility, 4 failed to meet inclusion criteria, 3 declined to participate and 2 were excluded for logistical reasons. Ten patients completed the study, 1 was excluded from final analysis. All patients recovered well without complication.

Demographic characteristics and baseline data are shown in Table 1 . Baseline $\mathrm{rSO}_{2}$ measured with the subjects sitting, fully awake and breathing room air, varied between $31 \%$ and $78 \%$. The left cerebral oximetry optode was removed, at the time of surgical preparation, for 5 included subjects. Analysis was therefore limited to data obtained from the right. Males were more frequently represented, malignant melanoma was the most prevalent diagnosis, and left-sided lesions were more frequent than rightsided lesions. The average time between measurements recorded at set point 1 and set point 2 was 17 minutes.

\subsection{Correlation between $\mathrm{PbrO}_{2}$ and $\mathrm{rSO}_{2}$}

Positive Spearman's correlation $(\mathrm{r}=0.50, p=0.036)$ was measured between $\mathrm{rSO}_{2}$ and $\mathrm{PbrO}_{2}$ (Fig. 1). Computation of $\mathrm{z}$-scores of $\mathrm{rSO}_{2}$ and $\mathrm{PbrO}_{2}$, allowing for ventilation strategies, showed no statistically significant differences.

\subsection{Influence of ventilation strategy on $\mathrm{PbrO}_{2}$}

$\mathrm{PbrO}_{2}$ increased from median 6.0, IQR 4.0-11.3 at set point $1\left(\mathrm{FiO}_{2} 0.3\right.$ and $\left.\mathrm{PaCO}_{2} 30 \mathrm{mmHg}\right)$ to median 22.5 , IQR 9.8-43.6 at set point $2\left(\mathrm{FiO}_{2} 1.0\right.$ and $\left.\mathrm{PaCO}_{2} 40 \mathrm{mmHg}\right)$ $p=0.015 . \mathrm{PbrO}_{2}$ increased in all subjects with the change in ventilation strategy.

\subsection{Influence of ventilation strategy on $\mathrm{rSO}_{2}$}

$\mathrm{rSO}_{2}$ increased from median 68.0, IQR 62.5-80.5 at set point 1 to median 83.0, IQR 74.0-90.0 at set point 2, $p=0.047$. $\mathrm{rSO}_{2}$ increased in all subjects with the change in ventilation strategy.
Table 1 Demographic characteristics and baseline data

\begin{tabular}{|c|c|c|c|c|}
\hline Variable & $N$ & Percent & Mean (Std) & Range \\
\hline Age & 9 & & $61.4(9.6)$ & $(45-72)$ \\
\hline \multicolumn{5}{|l|}{ Gender } \\
\hline $\mathrm{F}$ & 2 & 22.2 & & \\
\hline M & 7 & 77.8 & & \\
\hline \multicolumn{5}{|l|}{ ASA status } \\
\hline 2 & 1 & 11.1 & & \\
\hline 3 & 7 & 77.8 & & \\
\hline 4 & 1 & 11.1 & & \\
\hline $\mathrm{rSO} 2(\mathrm{~L})$ & 9 & & $68.6(13.5)$ & $(34-78)$ \\
\hline $\mathrm{rSO} 2(\mathrm{R})$ & 9 & & $67.8(14.7)$ & $(31-78)$ \\
\hline \multicolumn{5}{|l|}{$B P$} \\
\hline Systolic & 9 & & $134.7(18)$ & $(117-173)$ \\
\hline Diastolic & 9 & & $77.7(11.5)$ & $(67-106)$ \\
\hline \multicolumn{5}{|l|}{ Diagnosis } \\
\hline History of systemic malignant melanoma & 6 & 66.7 & & \\
\hline History of renal cell carcinoma & 2 & 22.2 & & \\
\hline Adenocarcinoma of breast & 1 & 11.1 & & \\
\hline \multicolumn{5}{|l|}{ Location (lobe) } \\
\hline Frontal & 4 & 44.4 & & \\
\hline Parietal & 1 & 11.1 & & \\
\hline Temporal & 3 & 33.3 & & \\
\hline Occipital & 1 & 11.1 & & \\
\hline \multicolumn{5}{|l|}{ Location (laterality) } \\
\hline Left & 8 & 88.9 & & \\
\hline Right & 1 & 11.1 & & \\
\hline
\end{tabular}

Demographic characteristics and baseline data. $r \mathrm{SO}_{2}$ : Regional cerebral oximetry, $\mathrm{BP}$ Blood pressure, Std: Standard deviation 


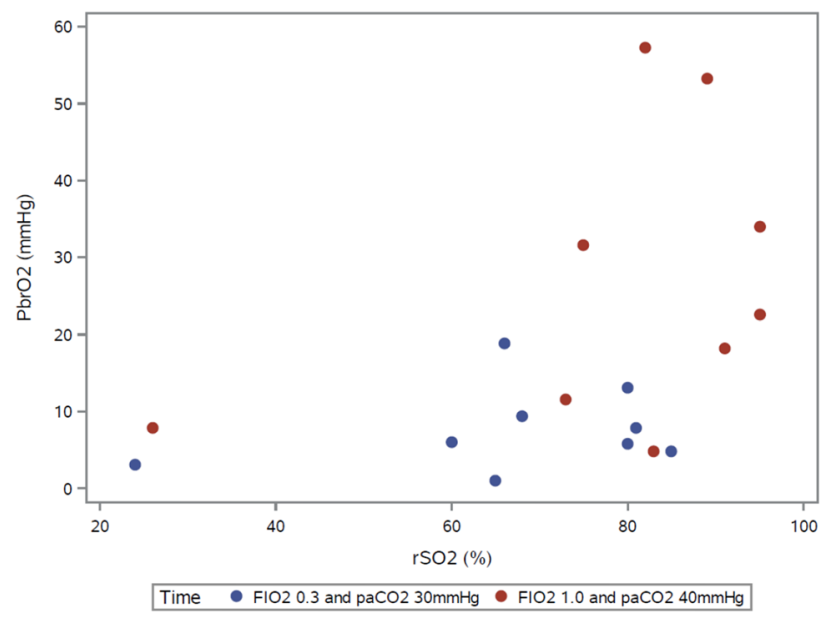

Fig. 1 Scatter plot illustrating the relationship between brain tissue oxygen tension $\left(\mathrm{PbrO}_{2}\right)$ and cerebral oximetry $\left(\mathrm{rSO}_{2}\right)$ at each ventilation set point

\subsection{Outliers}

A single outlier exhibited a $\mathrm{PbrO}_{2}$ of $162.2 \mathrm{mmHg}$ at $\mathrm{FiO}_{2}$ 1.0 and $\mathrm{PaCO}_{2} 40 \mathrm{mmHg}$, more than $100 \mathrm{mmHg}$ and 3 times greater than the nearest subject. This subject was identified as an extreme value using the Tuckey Fences approach and was excluded from final analysis. The patient was a 67-year-old male who underwent right temporal craniotomy for metastatic melanoma excision and displayed unremarkable baseline readings. Arterial gas tensions were within range displayed by other subjects and responded similarly to the change in ventilation strategy. Placement of the Licox probe followed standard processes. $\mathrm{rSO}_{2}$ increased from $49 \%$ at set point 1 to $69 \%$ at set point 2 .

\subsection{Arterial gas tension, hemodynamics, hematocrit, BIS, and anesthesia}

The changes in ventilation strategy resulted in significant increases in $\mathrm{PaO}_{2}$ and $\mathrm{PaCO}_{2}$ while the potential confounders of heart rate, arterial blood pressure and hematocrit remained unchanged. BIS and the infusion rate of anesthetic drugs was measured within target range; there was no difference between values at the study set points 1 and 2 (Table 2).

\section{Discussion}

We found evidence of positive correlation between $\mathrm{PbrO}_{2}$ and $\mathrm{rSO}_{2}$ measured in human brain, under the conditions of changing ventilation strategy. In addition, the combined intervention of increasing $\mathrm{FiO}_{2}$ and $\mathrm{PaCO}_{2}$ result in consistent and significant increases in both $\mathrm{PbrO}_{2}$ and $\mathrm{rSO}_{2}$. Our data provide evidence to support the rationale for changing ventilation strategy in response to measured or anticipated cerebral hypoxemia, for example during periods of cerebral hypoperfusion. Selection and recruitment proved to be extremely difficult, and progress was further impeded by the COVID-19 pandemic; the study was therefore discontinued early. However, the findings, which were statistically significant, can be regarded as hypothesis-generating and provide the basis for future investigation. Additionally, the experimental model developed for this study is novel, with wider implications for other related correlations (e.g., scalp electroencephalography and intracortical neurophysiology).

The limitations of cerebral NIRS techniques are well described [3]; it is very unlikely that all changes in $\mathrm{rSO}_{2}$ reflect true changes in brain tissue oxygen, necessitating confirmatory investigation against a more reliable and invasive measure of cerebral oxygenation for each separate effector
Table 2 Arterial gas tensions, hemodynamics, hematocrit and depth of anesthesia

\begin{tabular}{|c|c|c|c|c|c|}
\hline \multirow{2}{*}{$\begin{array}{l}N=9 \\
\text { Variable }\end{array}$} & \multicolumn{2}{|c|}{$\begin{array}{l}\text { FIO2 } 0.3 \text { and } \mathrm{paCO} 2 \\
30 \mathrm{mmHg}\end{array}$} & \multicolumn{2}{|c|}{$\begin{array}{l}\text { FIO2 } 1.0 \text { and } \mathrm{paCO} 2 \\
40 \mathrm{mmHg}\end{array}$} & \multirow{2}{*}{$\begin{array}{l}\text { Kruskal-Wallis } \\
\text { test by ranks } \\
p \text {-value }\end{array}$} \\
\hline & Mean (Std) & Range & Mean (Std) & Range & \\
\hline $\mathrm{PaCO} 2$ & $28.7(2.9)$ & $(2-34)$ & $41.3(3)$ & $(38-47)$ & 0.0003 \\
\hline $\mathrm{PaO} 2$ & $92.3(27.3)$ & $(62-150)$ & $343.3(67.9)$ & $(273-462)$ & 0.0003 \\
\hline Systolic BP & $125.4(24.5)$ & $(82-170)$ & $124.9(20.5)$ & $(101-154)$ & 0.8944 \\
\hline Diastolic BP & $69.9(11.8)$ & $(51-91)$ & $68.6(11)$ & $(53-88)$ & 0.8597 \\
\hline HR & $68.0(17.7)$ & $(47-100)$ & $64.1(16.8)$ & $(43-100)$ & 0.6269 \\
\hline HCT & $36.0(3.7)$ & $(29-41)$ & $35.7(4.8)$ & $(27-42)$ & 0.9645 \\
\hline BIS & $38.5(8.9)$ & $(21-47)$ & $41.1(5.2)$ & $(33-50)$ & 0.9157 \\
\hline Propofol mcg/kg/min & $78.3(14.6)$ & $(60-100)$ & $80.6(11.8)$ & $(60-100)$ & 0.651 \\
\hline Remifentanil $\mathrm{mcg} / \mathrm{kg} / \mathrm{min}$ & $0.1(0)$ & $(0.05-0.15)$ & $0.1(0)$ & $(0.05-0.15)$ & 0.7814 \\
\hline
\end{tabular}

Arterial gas tensions, hemodynamics, hematocrit, bispectral index, and anesthesia infusion rates at each ventilation set point. $H R$ : Heart rate, $H C T$ : Hematocrit, $B I S$ Bispectral index 
of $\mathrm{rSO}_{2}$. Our model does, however, provide an experimental paradigm within which such hypotheses could be tested.

The findings of a Spearman's correlation of 0.5 without a demonstrable difference between z-scores suggest a potential proxy relationship between monitors. However, at study set point 1 , while median $\mathrm{PbrO}_{2}$ was measured to be markedly low $(6 \mathrm{mmHg})$, median $\mathrm{rSO}_{2}$ was $68 \%$, a reading that would not alert anesthesiologists to the cerebral hypoxia detected invasively. The absolute value of $\mathrm{rSO}_{2}$ is difficult to interpret without context. Indeed, we have reported catastrophic ischemic neurological injury without noteworthy perturbation in cerebral oximetry values [15] and, despite meta-analysis, the effect of perioperative NIRS monitoring of the brain remains uncertain [16]. Trend monitoring has been previously suggested as the most appropriate application for cerebral oximetry [3]; our data support no more than this use.

It is concerning subjects displayed low brain tissue oxygen tensions (median $6 \mathrm{mmHg}$ ) with hematocrit and hemodynamics considered normal and, at $\mathrm{FiO}_{2} 0.3$ and $\mathrm{PaCO}_{2}$ $30 \mathrm{mmHg}$; anesthesiologists should be aware that such a ventilation strategy may result in cerebral hypoxemia for some patients. Sampling location in proximity to a metastatic lesion may be contributory. Increasing $\mathrm{FiO}_{2}$ and $\mathrm{PaCO}_{2}$ was found to be an effective strategy to improve brain tissue oxygen tension. It is likely that studies proving the influence of ventilation strategy on cerebral oximetry [17] reflect true oxygenation increments in the brain. This is especially important for studies conducted in patients at risk of cerebral hypoperfusion, for example, those undergoing carotid endarterectomy $[18,19]$ or surgery in the beach chair position [20].

The study has limitations. Most notably, the sample size was small and adversely impacted by difficult recruitment. The study was single center and limited to Caucasian subjects to minimize the variability of $\mathrm{rSO}_{2}$ findings due to differing skin pigmentation. It would have been of great interest to measure the effect of $\mathrm{FiO}_{2}$ and $\mathrm{PaCO}_{2}$ separately. However, by doing so, the period of cessation of surgery would have been unacceptably prolonged. We chose the combined intervention of increasing $\mathrm{FiO}_{2}$ and $\mathrm{PaCO}_{2}$ known to result in significant and clinically relevant increases in $\mathrm{rSO}_{2}$ [20]. Future study may allow $\mathrm{FiO}_{2}$ and $\mathrm{PaCO}_{2}$ to be considered independently. Other highly selective criteria for study inclusion inadvertently resulted in a predominantly male population with a predominant diagnosis of metastatic melanoma. The generalizability of the conclusions is thus limited. However, every patient regardless of gender, site of surgery, or presenting diagnosis responded with the same positive trajectory of cerebral oxygenation with increasing $\mathrm{FiO}_{2}$ and $\mathrm{PaCO}_{2}$, including the subject excluded for extreme values.

In conclusion, correlation between $\mathrm{rSO}_{2}$ and $\mathrm{PbrO}_{2}$ is evident but $\mathrm{rSO}_{2}$ is limited to detect marked cerebral hypoxemia. Increasing $\mathrm{FiO}_{2}$ and $\mathrm{PaCO}_{2}$ results in significant increases in cerebral oxygenation measured by both monitors; $\mathrm{rSO} 2$ can likely function as an effective trend monitor during changes in ventilation strategy. Finally, this novel model of non-invasive and invasive measurement of uninjured brain physiology may have wider applications.

Author contributions PP and GAM conceived of and designed the study. JB and AK recruited all subjects; PEV and MKT performed all anesthetics; JAH and DO performed all neurosurgical procedures. Data were collected by PP, JB and AM. Data analyses were completed by PP and GM. The first draft of the manuscript was written and prepared by PP and all authors made comment on and approve the final manuscript.

Funding Funding was provided by the Department of Anesthesiology, University of Michigan Medical School.

\section{Declarations}

Conflict of interest The authors have no conflicts of interest to declare.

\section{References}

1. Davie SN, Grocott HP. Impact of extracranial contamination on regional cerebral oxygen saturation: a comparison of three cerebral oximetry technologies. Anesthesiology. 2012;116(4):834-40. https://doi.org/10.1097/ALN.0b013e31824c00d7.

2. Casati A, Spreafico E, Putzu M, Fanelli G. New technology for noninvasive brain monitoring: continuous cerebral oximetry. Minerva Anestesiol. 2006;72(7-8):605-25.

3. Murkin JM, Arango M. Near-infrared spectroscopy as an index of brain and tissue oxygenation. Br J Anaesth. 2009;103(Suppl 1):i3-13. https://doi.org/10.1093/bja/aep299.

4. Heringlake M, Garbers C, Käbler JH, et al. Preoperative cerebral oxygen saturation and clinical outcomes in cardiac surgery. Anesthesiology. 2011;114(1):58-69. https://doi.org/10.1097/ALN. 0b013e3181fef34e.

5. Drummond JC, Sturaitis MK. Brain tissue oxygenation during dexmedetomidine administration in surgical patients with neurovascular injuries. J Neurosurg Anesthesiol. 2010;22(4):336-41. https://doi.org/10.1097/ANA.0b013e3181e4b7e3.

6. van den Brink WA, van Santbrink H, Steyerberg EW, et al. Brain oxygen tension in severe head injury. Neurosurgery. 2000;46(4):868-76. https://doi.org/10.1097/00006123-20000 4000-00018.

7. Ikeda K, MacLeod DB, Grocott HP, Moretti EW, Ames W, Vacchiano $\mathrm{C}$. The accuracy of a near-infrared spectroscopy cerebral oximetry device and its potential value for estimating jugular venous oxygen saturation. Anesth Analg. 2014;119(6):1381-92. https://doi.org/10.1213/ane.0000000000000463.

8. Rosenthal G, Furmanov A, Itshayek E, Shoshan Y, Singh V. Assessment of a noninvasive cerebral oxygenation monitor in patients with severe traumatic brain injury. J Neurosurg. 2014;120(4):901-7. https://doi.org/10.3171/2013.12.Jns131089.

9. Sun X, Ellis J, Corso PJ, Hill PC, Chen F, Lindsay J. Skin pigmentation interferes with the clinical measurement of regional cerebral oxygen saturation. Br J Anaesth. 2015;114(2):276-80. https://doi. org/10.1093/bja/aeu335.

10. van Santbrink H, Maas AI, Avezaat CJ. Continuous monitoring of partial pressure of brain tissue oxygen in patients with severe 
head injury. Neurosurgery. 1996;38(1):21-31. https://doi.org/10. 1097/00006123-199601000-00007.

11. Dings J, Meixensberger J, Jäger A, Roosen K. Clinical experience with 118 brain tissue oxygen partial pressure catheter probes. Neurosurgery. 1998;43(5):1082-95. https://doi.org/10.1097/ 00006123-199811000-00045.

12. Cerejo A, Silva PA, Vilarinho A, Dias C, Vaz R. Intraoperative brain oxygenation monitoring and vasospasm in aneurysmal subarachnoid hemorrhage. Neurol Res. 2012;34(2):181-6. https://doi. org/10.1179/1743132811y.0000000064.

13. Gelabert-González M, Fernández-Villa JM, Ginesta-Galan V. Intra-operative monitoring of brain tissue $\mathrm{O} 2$ (PtiO2) during aneurysm surgery. Acta Neurochir (Wien). 2002;144(9):863-6. https://doi.org/10.1007/s00701-002-0975-9.

14. Meng L, Cannesson M, Alexander BS, et al. Effect of phenylephrine and ephedrine bolus treatment on cerebral oxygenation in anaesthetized patients. Br J Anaesth. 2011;107(2):209-17. https:// doi.org/10.1093/bja/aer150.

15. Vlisides PE, Kunkler B, Thompson A, et al. Cerebrovascular disease and perioperative neurologic vulnerability: a prospective cohort study. Front Neurol. 2019;10:560. https://doi.org/10.3389/ fneur.2019.00560.

16. Yu Y, Zhang K, Zhang L, Zong H, Meng L, Han R. Cerebral near-infrared spectroscopy (NIRS) for perioperative monitoring of brain oxygenation in children and adults. Cochrane Database Syst Rev. 2018. https://doi.org/10.1002/14651858.CD010947.pub2.
17. Picton P, Shanks A, Dorje P, Mashour GA. The influence of basic ventilation strategies on cerebral oxygenation in anesthetized patients without vascular disease. J Clin Monit Comput. 2010;24(6):421-5. https://doi.org/10.1007/s10877-010-9265-x.

18. Picton P, Chambers J, Shanks A, Dorje P. The influence of inspired oxygen fraction and end-tidal carbon dioxide on post-cross-clamp cerebral oxygenation during carotid endarterectomy under general anesthesia. Anesth Analg. 2010;110(2):581-7. https://doi.org/10. 1213/ANE.0b013e3181c5f160.

19. Stoneham MD, Lodi O, de Beer TC, Sear JW. Increased oxygen administration improves cerebral oxygenation in patients undergoing awake carotid surgery. Anesth Analg. 2008;107(5):1670-5. https://doi.org/10.1213/ane.0b013e318184d6c3.

20. Picton P, Dering A, Alexander A, et al. Influence of ventilation strategies and anesthetic techniques on regional cerebral oximetry in the beach chair position: a prospective interventional study with a randomized comparison of two anesthetics. Anesthesiology. 2015;123(4):765-74. https://doi.org/10.1097/aln.0000000000 000798 .

Publisher's Note Springer Nature remains neutral with regard to jurisdictional claims in published maps and institutional affiliations. 